\title{
Article \\ S-Like Ribonuclease T2 Genes Are Induced during Mobilisation of Nutrients in Cotyledons from Common Bean
}

\author{
Mercedes Diaz-Baena, Elena Delgado-García, Manuel Pineda, Gregorio Galvez-Valdivieso (D) and Pedro Piedras * \\ Departamento de Botánica, Ecología y Fisiología Vegetal, Grupo de Fisiología Molecular y Biotecnología de Plantas, \\ Campus de Excelencia Internacional en Agroalimentación, Campus de Rabanales, Edif. Severo Ochoa, \\ Universidad de Córdoba, 14071 Córdoba, Spain; b42dibam@uco.es (M.D.-B.); b22degae@uco.es (E.D.-G.); \\ bb1piprm@uco.es (M.P.); b32gavag@uco.es (G.G.-V.) \\ * Correspondence: bb2pimop@uco.es
}

check for updates

Citation: Diaz-Baena, M.; Delgado-García, E.; Pineda, M.; Galvez-Valdivieso, G.; Piedras, P. S-Like Ribonuclease T2 Genes Are Induced during Mobilisation of Nutrients in Cotyledons from Common Bean. Agronomy 2021, 11, 490. https://doi.org/10.3390/ agronomy11030490

Academic Editor: Steven R. Larson

Received: 30 January 2021

Accepted: 3 March 2021

Published: 6 March 2021

Publisher's Note: MDPI stays neutral with regard to jurisdictional claims in published maps and institutional affiliations.

Copyright: (c) 2021 by the authors. Licensee MDPI, Basel, Switzerland. This article is an open access article distributed under the terms and conditions of the Creative Commons Attribution (CC BY) license (https:// creativecommons.org/licenses/by/ $4.0 /)$.

\begin{abstract}
Germination and seedling development are crucial phases in a plant's life cycle with economical and agronomical implications. The RNA quality in seeds is linked to seed viability, being an important agronomic trait since this leads to a loss in germination efficiency. In addition, RNA can be an important phosphorous reservoir in seeds, affecting the efficiency of the mobilisation of nutrients towards the seedlings. However, knowledge about the physiological function of ribonucleases during germination and seedling development is scarce. We analysed the ribonuclease activities of cotyledons during these processes and the expression of S-like ribonucleases T2. Ribonuclease activity was detected in cotyledons at 1 day after imbibition and the specific activity increased during germination and seedling development, reaching a maximal value at 10 days after imbibition. At this stage, the levels of proteins and RNA in cotyledons were very low. Using in-gel assays, three ribonucleases were detected with apparent molecular masses of 16,17 and $19 \mathrm{kDa}$ along cotyledon ontogeny. The S-like ribonucleases T2 family consists of four genes in common bean (PvRNS1 to PvRNS4). The expression of PvRNS1, PvRNS2 and PvRNS4 increased in the phase of nutrient mobilisation in cotyledons. The expression of PvRNS1 increased 1000 fold in cotyledons, from 1 to 6 days after imbibition. The suppression of the induction of ribonuclease activity and gene expression in decapitated seedlings suggests that the regulatory signal comes from the developing axes. These results clearly state that S-like ribonucleases T2 are involved in RNA turnover in cotyledons during seedling development.
\end{abstract}

Keywords: ribonuclease; Phaseolus vulgaris; seedlings; cotyledons; nutrient mobilisation; RNA

\section{Introduction}

Seed germination and post-germinative growth are two crucial phases in the life cycle of higher plants. The development of the new plant depends on the reserves accumulated in seeds during their formation, having to reach photoautotrophism and at the end of these periods before their nutrient reserves become exhausted. Therefore, these two processes involve high mobilisation of nutrients. Cotyledons are the storage organs in most dicotyledonous seeds, their main function of which is to provide nutrients to the developing axes until the seedlings become photosynthetic. Cotyledons from epigeously germinating seeds, such as common bean, follow several stages during germination and seedling development. After early embryonic axes development, cotyledons go through a photosynthetic phase, ending with senescence and nutrients exhaustion. Therefore, the cotyledons provide an excellent experimental system to analyse the changes occurring during nutrient mobilisation, given their role as nutrient supplier.

Germination sensu stricto starts with the imbibition of dry seeds and finishes with the radicle protrusion through the seed coat [1]. During this phase, both unbound metabolites and those obtained by the degradation of stored starch, proteins and oils in the embryo can provide the energy and nutrients needed for embryo growth and radicle protrusion [2]. 
During germination, the metabolism needs to be reactivated in a dense and oxygen-poor environment which involves changes in metabolic activities [2]. The mobilisation of nitrogen and phosphorous during germination is a process poorly understood in comparison with carbon, despite the high demand for these compounds by the developing axes to actively synthesize proteins and nucleic acids. In common bean, the main globulin is phaseolin, representing $34-50 \%$ of total protein in mature seed [3]. No differences in globulins were observed in common bean cotyledons during germination, whereas they became exhausted in embryonic axes before radicle protrusion [4]. However, during early seedling development, from day 4 to day 7 after imbibition, phaseolin content in cotyledons suffers a huge decrease, becoming exhausted in cotyledons at 11 days after imbibition [4]. Coincident with the degradation of phaseolin, enzymes involved in the degradation of ssDNA are induced [4], as well as allantoinase, an enzyme that catalyses the degradation of the ureide allantoin, a reaction product of the catabolism of purine nucleotides [5].

Nucleic acids are relatively abundant organic compounds in plant tissues. In addition to carbon, they contain nitrogen and phosphorus and, therefore, could play an important role as reservoirs for these compounds. Nucleic acids constitute the largest organic phosphorus reservoir in plants [6], RNA being the most abundant, since it represents around $85 \%$ of nucleic acids and $47 \%$ of organic phosphorus [6]. Due to the fact of this abundance, RNA could be crucial as a phosphorous supply in situations of high nutrient mobilisation, as RNA is present in dried seeds and can be transiently used for macromolecule synthesis during early phases of germination [7]. In addition, the integrity of this stored RNA is indicative of seed age and could be a good parameter to determine seed germination capacity $[7,8]$. The time span during which seeds remain viable or seed longevity is an important trait for agronomy, and the reduction of seed longevity has been attributed to oxidation of nucleic acids, in addition to lipids and proteins [9]. Stored RNA has a crucial role during gemination, which can proceed without the synthesis of new mRNAs, whereas it is arrested by the inhibition of translation [10,11]. The regulatory mechanisms that control the translation of the stored mRNA during germination has been recently reviewed [9]. This stored RNA is replaced as the germination progresses and cells start to use new transcripts for protein synthesis [12]. During the mobilisation phase, nucleic acids stored in cotyledons are degraded, and the resulting products might function as the $\mathrm{P}$ and $\mathrm{N}$ source for the developing seedlings. Despite this, knowledge about nucleic acid degradation in senescing cotyledons is very scarce [4].

Ribonucleases are the enzymes involved in RNA degradation, participating in a wide range of processes [13]. Due to the relative abundance of ribonucleic acid mentioned above, these enzymes could play a relevant role in physiological situations with high mobilisation of nutrients. Ribonucleases belonging to the T2 family are the most widely distributed and have been described in bacteria, fungi and eukaryotes [14]. In medicine, these enzymes have become of enormous interest because they seem to play a critical role in the pathophysiology of inflammation and cancer [15]. In plants, the biological role of S-like ribonucleases is poorly understood with suggested roles during Pi deficiency and in defence and stress responses, among others [16]. Members of this family have been described in Arabidopsis [17], rice [18] and common bean [19]. The plant RNase T2 family is divided into two subfamilies, S-RNases and S-like RNases [20]. The S-RNases are involved in gametophytic self-incompatibility, whereas the S-like RNases participate in a variety of processes including defence against biotic or abiotic stresses, salvage pathways and production of tRNA-derived small RNAs [16]. The RNase T2 family members are also classified into three classes (I to III) [21]; Class III includes the S-RNases and the Classes I and II the S-like RNases. Most of the RNase T2 family proteins are either secreted or targeted to cellular compartments of the secretory pathway [16].

In common bean, nuclease activities have been described during embryonic axes development [22] and cotyledons and leaf senescence [4,23], processes that requires high mobilisation of nutrients. Recently, the ribonuclease T2 family of Phaseolus vulgaris was described, and it was found that one of its members, PvRNS3, is induced in radicles of 
seedlings exposed to salt stress [19]. In this study, we assessed the changes in ribonuclease activities and in the expression of S-like ribonucleases T2 in cotyledons of common bean, examining the processes of germination and reserve mobilisation. We demonstrated that the expression of three genes coding for S-like T2 ribonucleases is induced in common bean cotyledons during the phase of high nutrient mobilisation to the developing seedlings. This study will contribute to the understanding of the role of nucleic acids under nutrient mobilisation situations in common bean, the most important legume for human consumption [24].

\section{Materials and Methods}

\subsection{Plant Material}

Common bean (Phaseolus vulgaris) seeds were sterilised by soaking in ethanol (30 s) and $0.2 \%(w / v)$ sodium hypochlorite $(5 \mathrm{~min})$ and washing repeatedly with distilled water. Seeds were placed in Petri dishes $(120 \mathrm{~mm}$ diameter $)$ with wet filter paper, and seeds were allowed to germinate in the growth chamber. Distilled water was added routinely to maintain humidity.

To obtain the material from cotyledons during germination and seedling development, the seedlings were maintained in Petri dishes until 6 days after start of imbibition (DAI). At that moment, seedlings were transferred to pots containing vermiculite:perlite $(3: 1, v / v)$ and watered with distilled water until 10 DAI.

Decapitated seedlings were obtained from 3 DAI seedlings by cutting the epicotyls with a razor blade just above the junction of the cotyledon and the embryonic axis. These decapitated seedlings, obtained by epicotyl removal, were maintained in wet Petri dishes for 3 additional days. Cotyledons were obtained from the decapitated seedlings (6 D) and from 3 and 6 DAI whole seedlings as controls.

Cotyledons from seedlings developed in the presence of nutrients were obtained by watering with the nutrient solution described in Galvez-Valdivieso et al. [25] enriched with $10 \mathrm{mM} \mathrm{KNO}_{3}$ during germination and early seedling development.

The collected plant materials were snap-frozen with liquid nitrogen and then stored in a $-80{ }^{\circ} \mathrm{C}$ freezer until further analysis.

\subsection{Preparation of Crude Extracts}

Frozen plant materials were ground to a fine powder with mortar and pestle in liquid nitrogen and stored at $-80^{\circ} \mathrm{C}$. Crude extracts were obtained from frozen powder by homogenisation with extraction buffer (50 mM TES buffer $(\mathrm{pH} 7.0)$ containing $0.15 \%(w / v)$ sodium deoxycholate using $4 \mathrm{~mL}$ of buffer per gram of powder. After centrifugation at $15,000 \times g$ for $10 \mathrm{~min}$ at $4{ }^{\circ} \mathrm{C}$, the supernatants were transferred to new tubes and considered as crude extracts.

\subsection{Total Soluble Protein Determination}

The soluble protein concentration was estimated by the Bradford method [26] using bovine serum albumin as the standard and a Bio-Rad system.

\subsection{Determination of Enzymatic Activities}

Ribonuclease activity in agarose gels: Total RNA $(1 \mu \mathrm{g})$ isolated from common bean radicles was incubated in a total volume of $10 \mu \mathrm{L}$ with crude extracts from common bean cotyledons in $50 \mathrm{mM}$ acetate $(\mathrm{pH} 5.5)$ at $37^{\circ} \mathrm{C}$. At times 0 and $10 \mathrm{~min}, 0.33 \mu \mathrm{L}$ of MOPS buffer pH 7 (200 mM MOPS, $50 \mathrm{mM}$ sodium acetate, $1 \mathrm{mM}$ EDTANa 2 ) and $0.6 \mu \mathrm{L}$ of formaldehyde were added to each tube and mixed. The reaction products were size fractionated on a denaturing formaldehyde agarose gel.

In-gel ribonuclease assays: Ribonuclease activity was determined as previously described by Diaz-Baena et al. [19]. Briefly, the gels contained RNA from torula yeast $\left(0.75 \mathrm{mg} \mathrm{mL}^{-1}\right.$, Sigma-Aldrich). The crude extracts were heated for $10 \mathrm{~min}$ at $65{ }^{\circ} \mathrm{C}$ in sample buffer before loading the gels. After electrophoresis, gels were incubated twice for $10 \mathrm{~min}$ at room temperature in $10 \mathrm{mM}$ of the indicated buffers containing 25\% (v/v) 2-propanol, and two 
additional times for $10 \mathrm{~min}$ at $4{ }^{\circ} \mathrm{C}$ in the same buffer without 2 -propanol at $4{ }^{\circ} \mathrm{C}$. The enzymatic reaction was developed at $50{ }^{\circ} \mathrm{C}$ in the same buffers at $100 \mathrm{mM}$ for a variable time (15-40 min). The gels were stained with toluidine blue O (0.2\%, Sigma-Aldrich, Madrid, Spain) for $5 \mathrm{~min}$ and washed repeatedly with distilled water. Gels were photographed and the images inverted.

\subsection{RNA Isolation}

Total RNA was extracted from $50 \mathrm{mg}$ of powdered tissue using the NZYol Reagent (NZYTECH, Lisbon, Portugal) following the manufacturer's instructions but including an additional $\mathrm{LiCl}$ precipitation step at the end of the procedure to improve the RNA quality. The RNA was finally dissolved in $20 \mu \mathrm{L}$ of water. The RNA was visualised using denaturing formaldehyde agarose gel. The RNA concentration was determined using a nanoVue Plus Spectrophotometer (GE Healthcare, Little Chalfont, UK).

\section{6. cDNA Synthesis}

Two $\mu g$ of total RNA were treated with RNAase-free DNAseI (NEB) to remove any traces of DNA. After treatment, the absence of contaminating genomic DNA was assessed by PCR. First strand cDNA was synthesised by reverse transcription of $2 \mu \mathrm{g}$ of total RNA using RevertAid reverse transcriptase (ThermoFisher, Madrid, Spain) with random hexamer primers.

\section{7. $q R T$}

Quantitative real-time PCR was performed as indicated previously [19]. Primers for the four ribonuclease T2 and the two reference (actin and ubiquitin) genes were the same as described previously [19]. At least three biological and three technical replicates were used for each experiment.

\subsection{Statistics}

All results are means of at least three independent experiments with at least two technical replicates. Values are mean \pm SE. Statistical analyses were performed with SPSS Statistics, version 25. Significant differences according to Tukey's test are indicated with different letters $(p \leq 0.05)$. A Student's $t$-test was performed comparing nutritive solution imbibition with control seedlings.

\section{Results}

\subsection{Total RNA and Protein during Cotyledon Development in Common Bean}

Total RNA and protein were analysed in cotyledons from common bean during germination ( 1 and 3 DAI), early seedling development ( 3 and 6 DAI) and seedling establishment and cotyledon senescence ( 6 and 10 DAI). The level of RNA was determined spectrophotometrically and diminished during these stages with the biggest reduction from 6 to 10 DAI (Figure 1A). The level of RNA was monitored by electrophoresis of total RNA in agarose gels (Figure 1B). During germination, the level of total rRNA remained unchanged, decreased at 6 DAI and it became almost undetectable in senescing cotyledons at 10 DAI (Figure 1B). The level of total soluble protein in the same crude extracts followed a pattern very similar to that of total RNA (Figure 1C).

\subsection{Ribonuclease Activities in Cotyledons of Common Bean}

Ribonuclease activity in cotyledons from common bean was determined using total RNA isolated from common bean radicles as substrate (Figure 2) following the degradation of RNA by electrophoresis. Ribonuclease activity was detected in crude extracts from cotyledons at $1 \mathrm{DAI}$, and the specific activity increased during seedling development reaching maximal RNA degradation at 10 DAI (Figure 2). A similar pattern of activity was obtained when the activity was normalised using the same amount of fresh weight per assay instead of total soluble protein (Figure S1). 
A

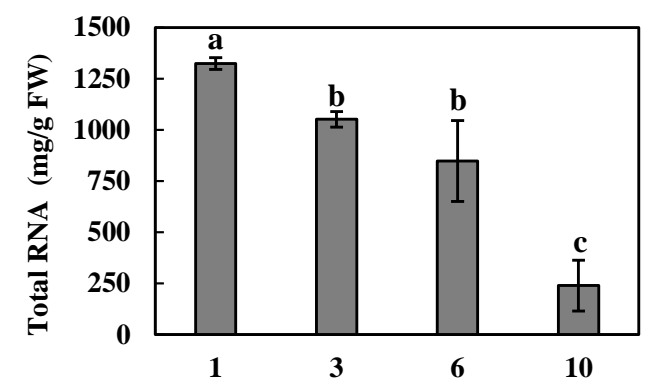

B

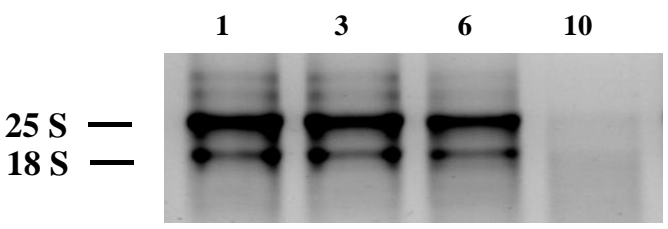

C

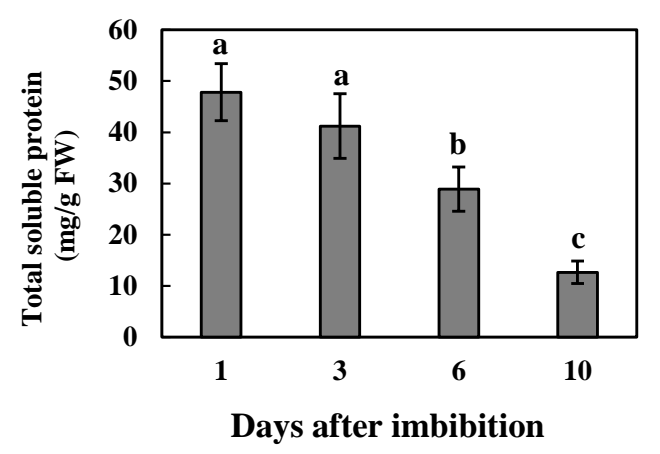

Figure 1. RNA and protein in cotyledons from common bean during germination and seedling development stages. (A) Total RNA was extracted from $50 \mathrm{mg}$ of powdered cotyledons collected at the indicated time after imbibition and resuspended in a final volume of $20 \mu \mathrm{L}$. The ribonucleic acid in each sample was quantified using spectrophotometer. (B) $1 \mu \mathrm{L}$ of total RNA was loaded on agarose gels and separated by electrophoresis. (C) Total soluble protein was determined in crude extracts obtained from the former cotyledons. Values are mean \pm SE of three independent experiments. Significant differences, according to Tukey's test, are indicated with different letters $(p \leq 0.05)$.

\section{Days after imbibition}

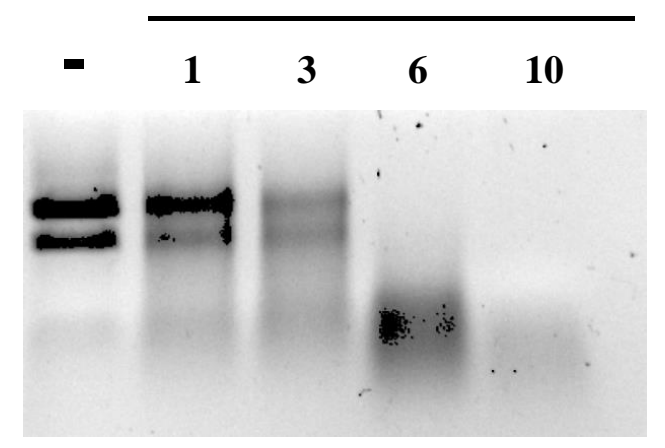

Figure 2. Ribonuclease activity in common bean during cotyledon development. Ribonuclease activity was determined in crude extracts obtained from cotyledons at the indicated days after start of imbibition (DAI) using $1 \mu \mathrm{g}$ of total RNA isolated from common bean radicles as substrates and equal amounts of total soluble protein in crude extracts. As control, the total RNA used as substrate was incubated in the absence of crude extracts (-). After enzymatic reactions, the remaining rRNA was visualised in agarose gels after electrophoresis. 
The ribonuclease activity was determined as well by in-gel assays with total RNA from torula yeast (Figure 3). In this assay, the activity was determined after electrophoresis in gels imbibed with RNA and provides information regarding the relative mobility of proteins with ribonuclease activity. In this case, the assay was performed loading crude extract obtained from the same amount of fresh weight per lane to avoid the interference of reserve protein degradation during the process. The activity was determined at two $\mathrm{pH}$ conditions to differentiate between acidic and neutral enzymes, following the same experimental procedure previously carried out for nuclease activities in common bean cotyledons [4]. Three ribonucleases activities were determined in cotyledons at 1 DAI with a relative mobility in semi-denaturing conditions of 16,17 and $19 \mathrm{kDa}$. Proteins with 17 and $19 \mathrm{kDa}$ showed similar activity in acetate $(\mathrm{pH} 5.5)$ and Tris- $\mathrm{HCl}(\mathrm{pH} 7)$ buffer, and their activity increased during seedling development (Figure 3). However, the $16 \mathrm{kDa}$ enzyme showed higher activity at $\mathrm{pH} 5.5$ than 7.0, and its activity decreased in cotyledons after germination (Figure 3).

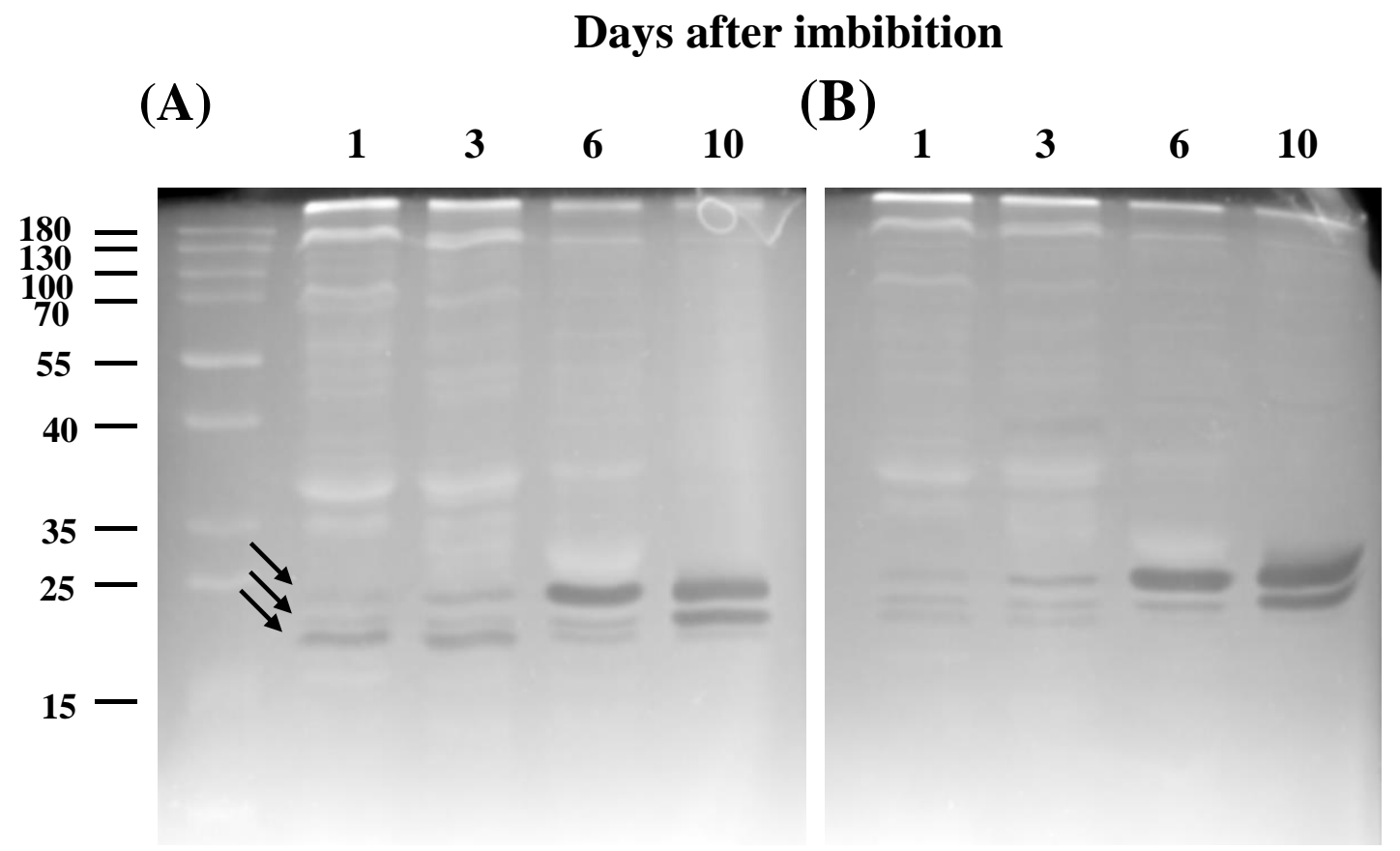

Figure 3. In-gel ribonuclease activity in common bean during cotyledon development. Ribonuclease activity was determined in acetate buffer $\mathrm{pH} 5.5$ (A) and Tris buffer $\mathrm{pH} 7$ (B) using crude extracts obtained from cotyledons at the indicated DAI. Equal amounts of crude extracts were loaded per lane. The mobility of molecular mass markers is shown on the left. After enzymatic assays, the gels were photographed and the images inverted. The main detected ribonucleases are marked with black arrows.

\subsection{S-Like Ribonuclease Genes Expression in Cotyledons of Common Bean}

The expression levels of T2 ribonucleases from common bean belonging to Class I and II (PvRNS1 to PvRNS4) were analysed in cotyledons during the germination and seedling development stages. The transcript levels of all the four genes were very low in cotyledons at 1 DAI and almost undetectable for PvRNS1, PvRNS2 and PvRNS3 (Figure 4). The level of PvRNS1 remained low at 3 DAI and increased significantly at 6 and 10 DAI, whereas expression of PvRNS2 increased through seedling development, although the increase was less marked than that of PvRNS1 (Figure 4). The level of expression of PvRNS3 remained relatively low and without any significant change through these stages (Figure 4). The expression of PvRNS4 progressively increased at 3 and 6 DAI and remained high at 10 DAI (Figure 4). The maximal expression of PvRNS1 and PvRNS4 was at 6 DAI, whereas that of PvRNS2 was at 10 DAI, with an increase in their transcript level of 970, 32 and 17 folds, respectively, in relation with the expression at 1 DAI. 
PvRNS1
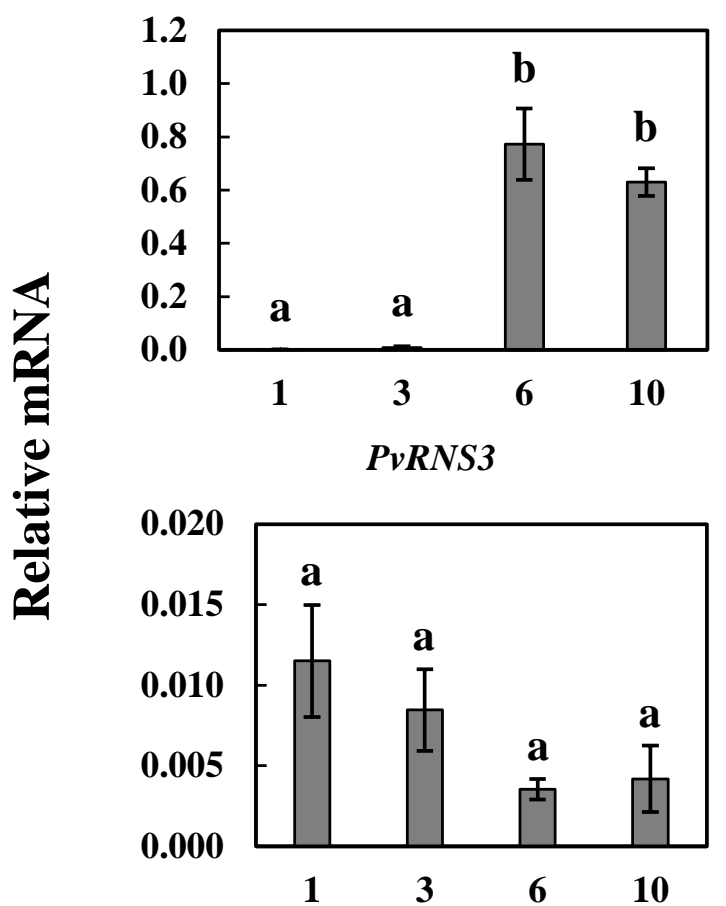

PvRNS2
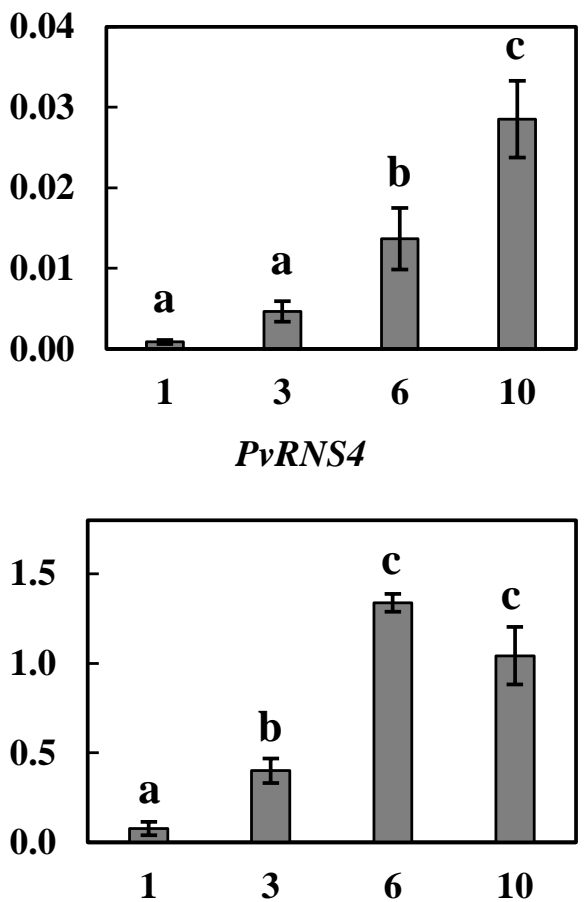

\section{Days after imbibition}

Figure 4. Expression pattern of PvNRS1 to PvRNS4 in cotyledons during germination and seedling development. S-like T2 ribonuclease expression analysis was performed using qRT-PCR on total RNA samples extracted from cotyledons of common bean at the indicated DAI. The relative expression level was normalised using the geometric mean of two reference genes and analysed using the $2^{-\Delta \mathrm{CT}}$ method. Values are mean $\pm \mathrm{SE}$ of four independent experiments with three technical replicates per experiment. Significant differences, according to Tukey's test, are indicated with different letters $(p \leq 0.05)$.

To test if the induction of these genes required the presence of the developing axes either as sinks demanding nutrients from cotyledons or as receptors of a signal derived from the expanding axes, the expression of the former genes and the ribonuclease activity were determined in 3 DAI decapitated seedlings obtained after removing the epicotyl of seedlings just above the junction of the cotyledons and the embryonic axes. The decapitated seedlings without epicotyls were maintained in the growth chamber for three additional days and cotyledons were isolated from these seedlings (6-D) as well that from normal developed seedlings at 3 (3) and 6 DAI (6) (Figure 5). In this situation, the increase of the $19 \mathrm{kDa}$ ribonuclease activity as well as the expression of PvRNS1, PvRNS2 and PvRNS4 were inhibited (Figure 5).

In the experiments presented above, seedling moisture was maintained with water to study the mobilisation of nutrients from the cotyledons. To determine if the response is due to the fact of stress by nutrient deficiency, we analysed the ribonuclease activities and the expression of S-like T2 ribonucleases in cotyledons from seedlings developed in the presence of nutrients (Figure 6). The availability of nutrients in the imbibition medium did not affect the activity of the three ribonucleases (Figure 6A,B) or the levels of transcript of the 4 S-like ribonucleases T2 (Figure 6C). 
(A)

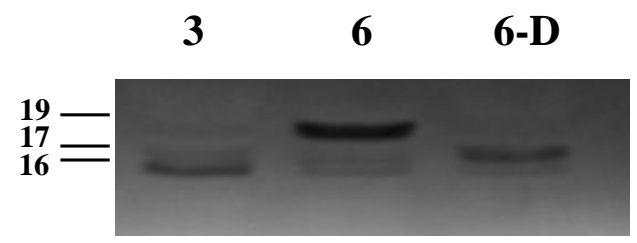

(B)

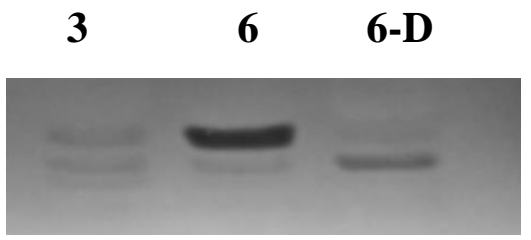

(C)

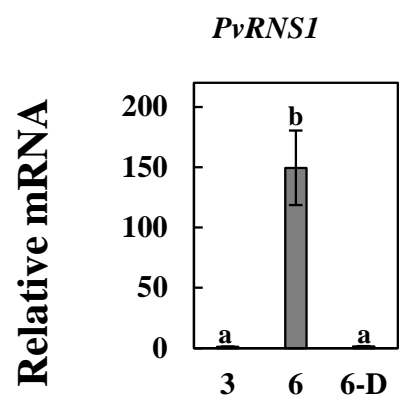

PvRNS2

PvRNS3

PvRNS4
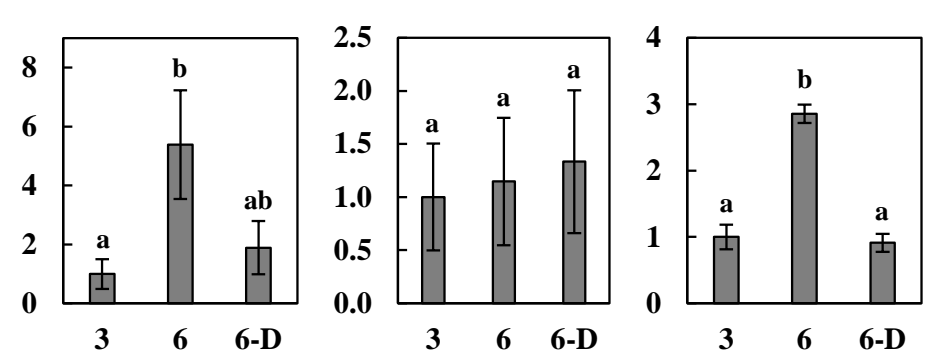

Figure 5. Ribonuclease activity and expression of S-like T2 ribonuclease genes in cotyledons from decapitated seedlings. Three days after imbibition, seedlings were decapitated by removing the epicotyls and placed in Petri dishes for three additional days (6-D). As controls, cotyledons from seedlings at 3 (3) and 6 (6) DAI were collected. Ribonuclease was determined using the same amount of crude extract per lane in acetate buffer pH 5.5 (A) and Tris buffer pH 7 (B). S-like T2 ribonuclease expression was determined by qRT-PCR and the data were normalised against the expression at 3 DAI for each gene $(\mathbf{C})$. Values are mean $\pm \mathrm{SE}$ of three independent experiments with three technical replicates per experiment. For each gene, the values were normalised to the values in cotyledons at 3 DAI. Significant differences, according to Tukey's test, are indicated with different letters $(p \leq 0.05)$.

(A)

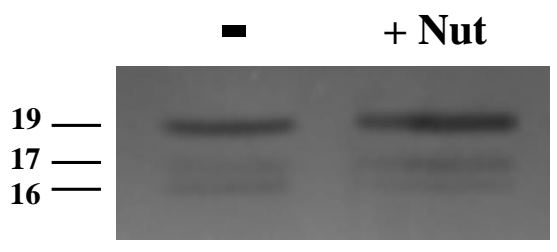

(C)

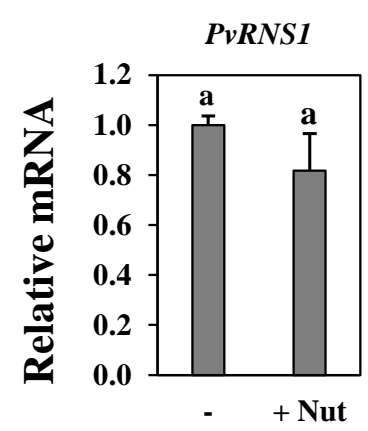

PvRNS2

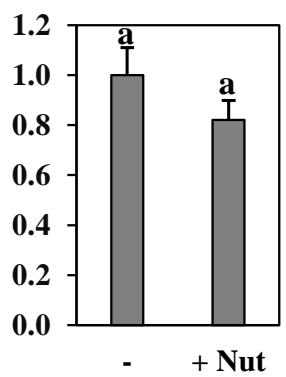

(B)

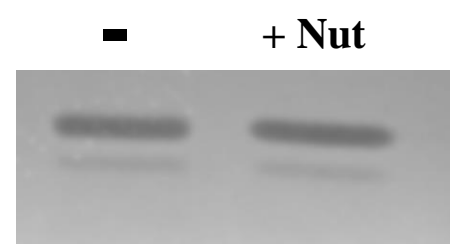

Figure 6. Ribonuclease activity and expression of S-like T2 ribonuclease genes in cotyledons from seedlings developed in the absence (-) or presence of nutrient solution (+Nut). Ribonuclease was determined using the same amount of crude extract per lane in acetate buffer $\mathrm{pH} 5.5$ (A) and Tris buffer $\mathrm{pH} 7$ (B). S-like T2 ribonuclease expression was determined by qRT-PCR (C). Values are mean \pm SE of four independent experiments with three technical replicates per experiment. For each gene, the values were normalised to the values in cotyledons from seedlings developed in water $(-)$. Significant differences, according to Tukey's test, are indicated with different letters $(p \leq 0.05)$. 


\section{Discussion}

In this paper, we have shown that different ribonucleases are induced in cotyledons during early seedling development, particularly three that belong to the S-like ribonucleases $\mathrm{T} 2$ family and, that this induction occurred in the nutrient mobilisation phase.

The mobilisation of nutrients during seedling development is a crucial agronomic challenge for correct plant establishment. The involvement of the RNase T2 in the degradation of RNA during this process has been poorly studied, although RNA is an important reservoir of organic $\mathrm{N}$ and $\mathrm{P}$ in plant cells [6]. Under nutrient starvation, RNA degradation could be a source for these elements. Thus, RNA yields are reduced in wheat under $\mathrm{N}$ starvation at the same time that a ribonuclease gene is upregulated, suggesting that RNA may be an important source of nutrients [27]. Likewise, in Saccharomyces cerevisiae, a ribonuclease T2 is majorly involved in RNA degradation under N starvation conditions [28]. Here, we described that ribonuclease activity in common bean increased in cotyledons, and we identified several ribonucleases in cotyledons.

Recently, we determined that PvRNS3 is induced in radicles subjected to salt stress [19]. However, this is the only gene that does not change significantly in cotyledons during germination and seedling development stages, whereas the other three S-like T2 ribonuclease genes, PvRNS1, PvRNS2 and PvRNS4, alter their expression in cotyledons during seedling development. Although, it is very probable that these three genes with altered expression codes induced the proteins; this requires further investigation since the activity assay was not performed in fully denaturing conditions to detect ribonuclease activity, and the proteins can alter its mobility due to the presence of post-translational modifications. The induction of these three genes seems to respond to signals derived from developing axes, since their induction was fully abolished in decapitated seedlings obtained after epicotyl removal. This process has been used to generate rejuvenated cotyledons, in which some parameters associated with cotyledon senescence were delayed. Thus, epicotyl removal resulted in cotyledons with lower protein degradation $[4,29]$ and higher photosynthesisrelated parameters [4,29-31] than normal grown seedlings. The developing axes have an elevated rate of respiration when rapidly growing that could lead to elevated Reactive Oxigen Species levels. In this way, either hydrogen peroxide as transportable signal or oxidative modification in the axes, can be considered in the cotyledons as signals to mobilise reserves from cotyledons to the rapidly growing axes [32]. Indeed, several antioxidant activities were much higher in axes than in cotyledons in common bean [33]. Alternatively, phytohormones derived from the developing axes can be the signals regulating this nutrient mobilisation. Indeed, it has been shown that the epicotyl removal in common bean resulted in a decrease in content of cytokinins [30]. Several hormones can interact with other signalling molecules resulting in a complex crosstalk network acting coordinatively during germination [34]. Furthermore, the induction of the three ribonuclease genes in cotyledons during seedling development was not associated with a stress response to nutrients deficiency by the seedling, since it was not affected by the presence of mineral nutrients during germination and early seedling development. Therefore, we can conclude that the induction of these genes should be predetermined by the developmental process needed for a correct seedling establishment.

PvRNS4 is the only T2 ribonuclease in common bean belonging to Class II [19]. In Arabidopsis, there is also a single gene within this class [17], whereas two genes are found in rice and soybean $[18,35]$. The genes belonging to Class II in Arabidopsis (RNS2) and rice (OsRNS2 and OsRNS6) are expressed in all the tissues [35-37]. Like AtRNS2, PvRNS4 is also predicted to be located in the vacuole. The function of AtRNS2 has been investigated in some detail, and it is tempting to speculate that PvRNS4 could have the same function as AtRNS2. It has been demonstrated that AtRNS2 is important to maintain RNA levels in cells, since rns 2 mutants accumulate rRNA in the cell [36]. To exert its function, the RNS2 protein needs to be located in the vacuole [37]. The Arabidopsis rns 2 null mutants or the mutants with misallocated RNS2 present a phenotype of constitutive autophagy [36,37]. Autophagy is a conserved mechanism by which plants degrade the unwanted material, 
such as proteins, or nucleic acid and entire organelles, after targeting to the vacuole [38]. This process is involved in the recycling and remobilisation of nutrients at the whole plant level [39-41] and in the responses to abiotic and biotic stresses [42,43]. Therefore, once the RNS2 protein is imported to the vacuole, it would act maintaining the RNA turnover, and the accumulation of RNA in the mutants would indicate that in Arabidopsis this function is not fully replaced by other RNS proteins.

PvRNS1 is the gene with the expression that increased the most in cotyledons, from 1 to 10 DAI (1000-fold). The analysis of the deduced PvRNS1 protein sequence predicts an extracellular localisation [19], and the pattern of expression during germination was different from that of PvRNS4, since PvRNS1 expression was almost undetectable in cotyledons at 1 and 3 DAI. Therefore, a different function for PvRNS1 protein in common bean can be hypothesised. PvRNS1 belongs to Class I RNases, enzymes that have been proposed to be involved in abiotic stress responses such as salt stress and phosphate deficiency responses $[13,18,19,35,44]$. The high level of expression of PvRNS1 during the high nutrient mobilisation phase in cotyledons in the absence of external stress could mean a main role in ribonucleic acid mobilisation during seedling development. Efficient mobilisation processes in cotyledons could improve plant fitness. In common bean seedlings, the removal of cotyledons leads to a slowdown in the growth of the isolated axes [4]. In this way, the knowledge of the mechanisms involved in nutrient mobilisation at the whole-plant level during leaf senescence has been proposed as a way to improve important agronomic traits in crops species such as seed production and quality [45]. Most of the studies have been focused on nitrogen mobilisation with proteins as the main nitrogen source, but the role of nucleic acid could have been underestimated, since it is a non-negligible source of nitrogen at the same time that it is a primary source of phosphorous [45].

In this paper we have demonstrated the induction of ribonuclease activities in cotyledons of common bean during the high nutrient mobilisation phase, and we have shown that S-like ribonuclease genes are induced during this process. PvRNS1 is the gene most highly induced in cotyledons from 1 to 6 days after imbibition with a relative induction of 1000 fold, and it is a good candidate to have a relevant role during the mobilisation of RNA in cotyledons and, therefore, further characterisation of the gene will be interesting in order to increase knowledge of RNA turnover. Since the induction seems to be dependent on signals derived from developing axes and independent from the presence of nutrients in the surroundings media, it will also be interesting to address this point to improve the efficient seedling establishment of important crops such as common bean.

Supplementary Materials: The following are available online at https: / /www.mdpi.com/2073-439 5/11/3/490/s1, Figure S1: Ribonuclease activity in common bean during cotyledon development.

Author Contributions: Conceptualization, G.G.-V. and P.P.; methodology, G.G.-V. and P.P.; validation, G.G.-V. and P.P.; formal analysis, G.G.-V., M.P. and P.P.; investigation, M.D.-B. and E.D.-G.; data curation, G.G.-V. and P.P.; writing—original draft preparation, P.P.; writing-review and editing, G.G.-V., M.P. and P.P.; funding acquisition, P.P. and M.P. All authors have read and agreed to the published version of the manuscript.

Funding: This work was funded by Ministerio de Economía y Competitividad (AGL2015-69554) and Plan Andaluz de Investigación (BIO115).

Institutional Review Board Statement: Not applicable.

Informed Consent Statement: Not applicable.

Data Availability Statement: Data are contained within the article.

Acknowledgments: M. Diaz-Baena acknowledges the support of a fellowship from Universidad de Córdoba (Contratos Predoctorales UCO), Spain. We thank Alfonso Muñoz for critical reading of the manuscript. 
Conflicts of Interest: The authors declare no conflict of interest. The funders had no role in the design of the study; in the collection, analyses, or interpretation of data; in the writing of the manuscript, or in the decision to publish the results.

\section{References}

1. Rajjou, L.; Duval, M.; Galardo, K.; Catusse, J.; Bally, J.; Job, C.; Job, D. Seed germination and vigor. Annu. Rev. Plant Biol. 2012, 63, 507-533. [CrossRef] [PubMed]

2. Rosental, L.; Nonogaki, H.; Fait, A. Activation and regulation of primary metabolism during seed germination. Seed Sci. Res. 2014, 24, 1-15. [CrossRef]

3. Harada, T.; Miyairi, K.; Murai, N. Trimeric glycoproteins of bean seed storage protein phaseolin were purified from baculovirusinfected insect Sf9 cells for use of structural study. Plant Sci. 2010, 179, 123-132. [CrossRef]

4. Lambert, R.; Cabello-Diaz, J.M.; Quiles, F.A.; Piedras, P. Identification of nucleases related to nutrient mobilization in senescing cotyledons from French bean. Acta Physiol. Plant. 2016, 38, 11. [CrossRef]

5. Quiles, F.A.; Raso, M.J.; Pineda, M.; Piedras, P. Ureide metabolism during seedling development in French bean (Phaseolus vulgaris). Physiol. Plantarum 2009, 135, 19-28. [CrossRef] [PubMed]

6. Veneklaas, E.J.; Lambers, H.; Bragg, J.; Finnegan, P.M.; Lovelock, C.E.; Plaxton, W.C.; Price, C.A.; Scheible, W.; Shane, M.W.; White, P.J Opportunities for improving phosphorus-use efficiency in crop plants. New Phytol. 2012, 195, 306-320. [CrossRef] [PubMed]

7. Zhao, L.; Wang, S.; Fu, Y.B.; Wang, H. Arabidopsis seed stored mRNAs are degraded constantly over aging time, as revealed by new quantification methods. Front. Plant Sci. 2020, 10, 1764. [CrossRef]

8. Fleming, M.B.; Hill, L.M.; Walters, C. The kinetics of ageing in dry-stored seeds: A comparison of viability loss and RNA degradation in unique legacy seed collections. Ann. Bot. 2019, 123, 1133-1146. [CrossRef] [PubMed]

9. Sano, N.; Rajjou, L.; North, H.M. Lost in translation: Physiological roles of stored mRNAs in seed germination. Plants 2020, 9, 347. [CrossRef]

10. Rajjou, L.; Gallardo, K.; Debeaujon, I.; Vandekerckhove, J.; Job, C.; Job, D. The effect of a-Amanitin on the Arabidopsis seed proteome highlights the distinct roles of stored and neosynthesized mRNAs during germination. Plant Physiol. 2004, 134, 1598-1613. [CrossRef] [PubMed]

11. Sano, N.; Permana, H.; Kumada, R.; Shinozaki, Y.; Tanabata, T.; Yamada, T.; Hirasawa, T.; Kanekatsu, M. Proteomic analysis of embryonic proteins synthesized from long-lived mRNAs during germination of rice seeds. Plant Cell Physiol. 2012, 53, 687-698. [CrossRef]

12. Bewley, J.D. Seed germination and dormancy. Plant Cell 1997, 9, 1055-1066. [CrossRef] [PubMed]

13. Zheng, J.; Wang, Y.; He, Y.; Zhou, J.; Li, Y.; Liu, Q.; Xie, X. Overexpression of an S-like ribonuclease gene, OsRNS4, confers enhanced tolerance to high salinity and hyposensitivity to phytochrome-mediated light signals in rice. Plant Sci. 2014, 214, 99-105. [CrossRef]

14. Luhtala, N.; Parker, R. T2 Family ribonucleases: Ancient enzymes with diverse roles. Trends Biochem. Sci. 2010, 35, 253-259. [CrossRef] [PubMed]

15. $\mathrm{Wu}, \mathrm{L} . ; \mathrm{Xu}, \mathrm{Y} . ; \mathrm{Zhao}, \mathrm{H} . ; \mathrm{Li}, \mathrm{Y} . \mathrm{RNase} \mathrm{T} 2$ in inflammation and cancer: Immunological and biological views. Front. Immunol. 2020, 11, 1554. [CrossRef] [PubMed]

16. MacIntosh, G.C.; Castandet, B. Organellar and secretory ribonucleases: Major players in plant RNA homeostasis. Plant Physiol. 2020, 183, 1438-1452. [CrossRef] [PubMed]

17. Igic, B.; Kohn, J.R. Evolutionary relationships among self-incompatibility RNases. Proc. Natl. Acad. Sci. USA 2001, 98, 13167-13171. [CrossRef]

18. MacIntosh, G.C.; Hillwig, M.S.; Meyer, A.; Flagel, L. RNase T2 genes from rice and the evolution of secretory ribonucleases in plants. Mol. Genet. Genom. 2010, 283, 381-396. [CrossRef] [PubMed]

19. Diaz-Baena, M.; Galvez-Valdivieso, G.; Delgado-Garcia, E.; Pineda, M.; Piedras, P. Nuclease and ribonuclease activities in response to salt stress: Identification of PvRNS3, a T2/S-like ribonuclease induced in common bean radicles by salt stress. Plant Physiol. Biochem. 2020, 147, 235-241. [CrossRef] [PubMed]

20. Green, P.J. The ribonucleases of higher plants. Annu. Rev. Plant Physiol. Plant Mol. Biol. 1994, 45, 421-445. [CrossRef]

21. Ramanauskas, K.; Igić, B. The evolutionary history of plant T2/S-type ribonucleases. PeerJ 2017, 5, e3790. [CrossRef] [PubMed]

22. Lambert, R.; Quiles, F.A.; Cabello-Diaz, J.M.; Piedras, P. Purification and identification of a nuclease activity in embryo axes from French bean. Plant Sci. 2014, 224, 137-143. [CrossRef] [PubMed]

23. Lambert, R.; Quiles, F.A.; Galvez-Valdivieso, G.; Piedras, P. Nucleases activities during French bean leaf aging and dark-induced senescence. J. Plant Physiol. 2017, 218, 235-242. [CrossRef] [PubMed]

24. Broughton, W.J.; Hernandez, G.; Blair, M.; Beebe, S.; Gepts, P.; Vanderleyden, J. Beans (Phaseolus spp.)—Model food legumes. Plant Soil 2003, 252, 55-122. [CrossRef]

25. Galvez-Valdivieso, G.; Alamillo, J.M.; Fernandez, J.; Pineda, M. Molecular characterization of PVAS3: An asparagine synthetase gene from common bean prevailing in developing organs. J. Plant Physiol. 2013, 170, 1484-1490. [CrossRef] [PubMed]

26. Bradford, M.M. Rapid and sensitive method for quantitation of microgram quantities of protein utilizing principle of protein-dye binding. Anal. Biochem. 1976, 72, 248-254. [CrossRef] 
27. Melino, V.J.; Casartelli, A.; George, J.; Rupasinghe, T.; Roessner, U.; Okamoto, M.; Heuer, S. RNA catabolites contribute to the nitrogen pool and support growth recovery of wheat. Front. Plant Sci. 2018, 9, 1539. [CrossRef] [PubMed]

28. Huang, H.H.; Kawamata, T.; Horie, T.; Tsugawa, H.; Nakayama, Y.; Ohsumi, Y.; Fukusaki, E. Bulk RNA degradation by nitrogen starvation-induced autophagy in yeast. EMBO J. 2015, 34, 154-168. [CrossRef]

29. Ananieva, K.; Ananiev, E.D.; Mishev, K.; Georgieva, K.; Tzvetkova, N.; Van Staden, J. Changes in photosynthetic capacity and polypeptide patterns during natural senescence and rejuvenation of Cucurbita pepo L (zucchini) cotyledons. Plant Growth Regul. 2008, 54, 23-29. [CrossRef]

30. Wilhelmova, N.; Prochazkova, D.; Machackova, I.; Vagner, M.; Srbova, M.; Wilhelm, J. The role of cytokinins and ethylene in bean cotyledon senescence. The effect of free radicals. Biol. Plantarum 2004, 48, 523-529. [CrossRef]

31. Jasid, S.; Galatro, A.; Villordo, J.J.; Puntarulo, S.; Simontacchi, M. Role of nitric oxide in soybean cotyledon senescence. Plant Sci. 2009, 176, 662-668. [CrossRef]

32. Verma, G.; Mishra, S.; Sangwan, N.; Sharma, S. Reactive oxygen species mediate axis-cotyledon signaling to induce reserve mobilization during germination and seedling establishment in Vigna Radiat. J. Plant Physiol. 2015, 184, 79-88. [CrossRef]

33. Quiles, F.A.; Galvez-Valdivieso, G.; Guerrero-Casado, J.; Pineda, M.; Piedras, P. Relationship between ureidic/amidic metabolism and antioxidant enzymatic activities in legume seedlings. Plant Physiol. Biochem. 2019, 138, 1-8. [CrossRef]

34. Wojtyla, L.; Lechowska, K.; Kubala, S.; Garnczarska, M. Different Modes of Hydrogen Peroxide Action during Seed Germination. Front. Plant Sci. 2016, 7, 66. [CrossRef] [PubMed]

35. Gho, Y.S.; Choi, H.; Moon, S.; Song, M.Y.; Park, H.; Kim, D.H.; Ha, S.H.; Jung, K.H. Phosphate-starvation-inducible S-like RNase genes in rice are involved in phosphate source recycling by RNA decay. Front. Plant Sci. 2020, 11, 585561. [CrossRef] [PubMed]

36. Hillwig, M.S.; Contento, A.L.; Meyer, A.; Ebany, D.; Bassham, D.C.; Macintosh, G.C. RNS2, a conserved member of the RNase T2 family, is necessary for ribosomal RNA decay in plants. Proc. Natl. Acad. Sci. USA 2011, 108, 1093-1098. [CrossRef]

37. Floyd, B.E.; Mugume, Y.; Morriss, S.C.; MacIntosh, G.C.; Bassham, D.C. Localization of RNS2 ribonuclease to the vacuole is required for its role in cellular homeostasis. Planta 2017, 245, 779-792. [CrossRef]

38. Marshall, R.S.; Vierstra, R.D. Autophagy: The master of bulk and selective recycling. Annu. Rev. Plant Biol. 2018, 69, 173-208. [CrossRef] [PubMed]

39. Masclaux-Daubresse, C.; Chen, Q.; Have, M. Regulation of nutrient recycling via autophagy. Curr. Opin. Plant Biol. 2017, 39, 8-17. [CrossRef] [PubMed]

40. Chen, Q.W.; Shinozaki, D.; Luo, J.; Pottier, M.; Have, M.; Marmagne, A.; Reisdorf-Cren, M.; Chardon, F.; Thomine, S.; Yoshimoto, K.; et al. Autophagy and nutrients management in plants. Cells 2019, 8, 1426. [CrossRef]

41. Li, Y.; Lin, Y.; Li, X.; Guo, S.; Huang, Y.; Xie, Q. Autophagy dances with phytohormones upon multiple stresses. Plants 2020, 9, 1038. [CrossRef] [PubMed]

42. Avin-Wittenberg, T. Autophagy and its role in plant abiotic stress management. Plant Cell Environ. 2019, 42, 1045-1053. [CrossRef] [PubMed]

43. Signorelli, S.; Tarkowski, K.P.; den Ende, W.V.; Bassham, D.C. Linking autophagy to abiotic and biotic stress response. Trends Plant Sci. 2019, 24, 413-429. [CrossRef] [PubMed]

44. Bariola, P.A.; Howard, C.J.; Taylor, C.B.; Verburg, M.T.; Jaglan, V.D.; Green, P.J. The Arabidopsis ribonuclease gene RNS1 is tightly controlled in response to phosphate limitation. Plant J. 1994, 6, 673-685. [CrossRef] [PubMed]

45. Have, M.; Marmagne, A.; Chardon, F.; Masclaux-Daubresse, C. Nitrogen remobilization during leaf senescence: Lessons from Arabidopsis to crops. J. Exp. Bot. 2017, 68, 2513-2529. [PubMed] 